\title{
HUBUNGAN KETERAMPILAN KOMUNIKASI ABAD 21 DAN KETERAMPILAN PEMECAHAN MASALAH MAHASISWA PENDIDIKAN FISIKA
}

\author{
Yanti Sofi Makiyah', Ifa Rifatul Mahmudah1, Dwi Sulistyaningsih¹ dan Ernita Susanti1 \\ ${ }^{1}$ Program Studi Pendidikan Fisika, Fakultas Keguruan dan Ilmu Pendidikan, Universitas \\ Siliwangi, Indonesia \\ E-mail: yanti.sofi@unsil.ac.id
}

\begin{abstract}
ABSTRAK
Keterampilan komunikasi (Communication Skills) dan keterampilan pemecahan masalah (Problem Solving Skills) merupakan keterampilan yang sangat dibutuhkan dan harus dimiliki oleh mahasiswa calon guru di abad 21. Tujuan penelitian ini untuk menganalisis hubungan antara keterampilan komunikasi abad 21 dan keterampilan pemecahan masalah mahasiswa pendidikan fisika pada mata kuliah mekanika. Subjek penelitian yaitu 65 mahasiswa pendidikan fisika yang mengambil mata kuliah mekanika tahun akademik 2019/2020. Instrumen penelitian yang digunakan yaitu lembar observasi keterampilan komunikasi, tes uraian berkasus dan wawancara yang dilakukan oleh tiga orang pewawancara. Hasil analisis data diperoleh korelasi positif dalam kategori sedang antara keterampilan komunikasi terhadap keterampilan pemecahan masalah dengan nilai koefisien korelasi yaitu 0,50. Adapun kontribusi keterampilan komunikasi terhadap keterampilan pemecahan masalah sebesar $25 \%$ sehingga dapat disimpulkan bahwa terdapat hubungan yang signifikan antara keterampilan komunikasi (Communication Skills) dan keterampilan pemecahan masalah (Problem Solving Skills) di kelas mekanika tahun akademik 2019/2020.
\end{abstract}

Kata kunci: Keterampilan Komunikasi, Keterampilan Pemecahan Masalah

\begin{abstract}
Communication skills and problem-solving skills are indispensable and must be trained to pre-service physics teachers in the 21st century. The purpose of this study was to analyze the relationship between communication skills and problem-solving skills of physics education students at mechanics courses. The research subjects were 65 physics education students 2019/2020 academic year. The research instrument used communication skills observation sheet, case description test and an interview conducted by three observers. The results of data analysis showed positive correlation between communication skills and problem-solving skills in medium category $(0.50)$ and the contribution of communication skills to problem solving skills by $25 \%$. There is a significant relationship between communication skills and problem-solving skills in physics education students 2019/2020 academic year.
\end{abstract}

Keywords: Communication Skills, Problem Solving Skills

DOI: http://dx.doi.org/10.15575/jotalp.v6i1.9412

Received: 29 Agustus 2020 ; Accepted: 21 Januari 2021 ; Published: 28 Februari 2021 


\section{PENDAHULUAN}

Keterampilan komunikasi (communication skill) dan keterampilan pemecahan masalah (problem solving skill) merupakan keterampilan abad 21 yang sangat perlu dilatihkan kepada mahasiswa pendidikan fisika sebagai calon guru yang profesional. Hal tersebut sesuai dengan Malik dkk (2020) yang menyatakan bahwa terdapat lima keterampilan yang harus dilatihkan dan dikembangkan pada abad 21 yaitu keterampilan pemecahan masalah, keterampilan berpikir kritis, keterampilan berpikir kreatif, keterampilan komunikasi dan keterampilan kolaboratif. Selain itu, Duta (2015) menyatakan bahwa keterampilan komunikasi merupakan keterampilan yang sangat penting terutama untuk guru dalam menyampaikan ide, informasi dan pendapat yang disampaikan kepada siswa sehingga disyaratkan memiliki keterampilan komunikasi yang efektif sehingga keterampilan komunikasi harus dimiliki pada abad 21 oleh mahasiswa calon guru agar dapat berkomunikasi dengan efektif, efisien dan menyenangkan terutama dalam menyelesaikan permasalahan dan mengambil keputusan dalam pembelajaran di kelas. Hal ini sesuai dengan pernyataan Argaw (2019) yang menyatakan bahwa calon guru profesional harus terampil dalam berkomunikasi dan memecahkan permasalahan yang dihadapi sehingga dapat merancang pembelajaran yang dapat menarik dan bermakna.

Pada era teknologi digital saat ini, mahasiswa calon guru fisika dituntut harus terampil berkomunikasi baik secara langsung ataupun dalam bentuk tulisan dalam mengatasi permasalahan yang sedang dihadapi terkait pembelajaran di era new normal pandemi covid19 ini. Rahman (2020) menyatakan hal yang sama bahwa di era kemajuan teknologi saat ini melalui berkomunikasi mahasiswa calon guru dapat menyelesaikan masalah, melakukan edukasi dan mengambil keputusan. Keterampilan komunikasi menjadi keterampilan penting berdasarkan Standar Nasional Pendidikan Tinggi dengan salah satu rumusan capaian pembelajarannya yaitu mampu menyusun ide, hasil pemikiran dan argumen saintifik secara bertanggung jawab dan beretika akademik, serta mengkomunikasikannya melalui media kepada masyarakat akademik dan masyarakat luas (Saputro, 2020). Ini sejalan dengan yang dikemukakan oleh Makiyah (2019) bahwa setiap universitas perlu membekali mahasiswa dengan keterampilan abad ke-21 melalui model pembelajaran yang dapat melatihkan keterampilan komunikasi dan keterampilan pemecahan masalah dengan memperhatikan perkembangan teknologi informasi dan komunikasi.

Berdasarkan hasil studi pendahuluan berupa wawancara dan pengamatan pembelajaran di kelas diketahui bahwa pembelajaran sebelumnya belum melatihkan keterampilan komunikasi dan keterampilan pemecahan masalah. Oleh karena itu, peneliti tertarik menerapkan model problem solving untuk melatihkan keterampilan pemecahan masalah dan keterampilan komunikasi. Selain itu, peneliti tertarik menganalisis bagaimana hubungan keterampilan komunikasi abad 21 dan keterampilan pemecahan masalah mahasiswa pendidikan fisika. Penelitian sebelumnya yang dilakukan oleh Pahlevi (2020) menunjukkan bahwa model problem solving praktis dan efektif dalam meningkatkan keterampilan komunikasi dan penguasaan konsep asam basa. Hasil penelitian lain yang dilakukan oleh Safitri (2019) dan Muhajir (2015) juga menunjukkan bahwa model problem solving memberikan pengaruh besar dan positif dalam meningkatkan keterampilan komunikasi, kolaborasi dan literasi sains mahasiswa. Model problem solving tidak hanya melatihkan keterampilan komunikasi dan keterampilan pemecahan masalah saja tetapi juga melatihan keterampilan berpikir dimulai dari mencari data sampai merumuskan kesimpulan sehingga mahasiswa mendapatkan pembelajaran yang bermakna (Zulianti, 2017). Adapun langkahlangkah dalam penerapan model probelm solving yaitu sebagai berikut: (1) Mengorientasikan mahasiswa pada masalah. (2) Mencari data dan informasi yang dapat digunakan untuk 
memecahkan masalah yang diberikan. (3) Menetapkan jawaban sementara dari masalah. (4) Menguji kebenaran jawaban sementara. (5) Menarik kesimpulan.

Keterampilan komunikasi abad 21 yang dilatihkan dan diamati terdiri dari 3 aspek yaitu sistematika/format, penggunaan bahasa dan kelengkapan isi serta urutan isi (Medriati, 2020). Pada aspek sistematika/format diamati kemampuan menyampaikan gagasan/hasil diskusi. Untuk aspek penggunaan bahasa diamati bahasa yang digunakan tersebut santun, jelas, dan komunikatif. Pada aspek kelengkapan isi dan urutan isi diamati bagaimana menceritakan atau menyampaikan pokok-pokok sesuai tema.

Adapun indikator keterampilan pemecahan masalah yang diamati dan dinilai yaitu mendefinisikan masalah, memeriksa masalah, merencanakan solusi, melaksanakan rencana yang telah dibuat dan mengevaluasi (Novitasari, 2015). Indikator keterampilan pemecahan masalah tersebut merupakan keterampilan dasar dari keterampilan pemecahan masalah (Hakkinen, 2017). Keterampilan ini sangat dibutuhkan pada era new normal dengan tingkat permasalahan yang kompleks pada permasalahan pembelajaran saat ini.

Berdasarkan penelitian yang telah dilakukan sebelumnya oleh Medrianti (2020) keterampilan komunikasi dibutuhkan dalam mengemukakan ide dan membantu dalam proses penyusunan pikiran serta merupakan dasar untuk memecahkan masalah sehingga diprediksikan dapat memiliki korelasi yang positif terhadap keterampilan pemecahan masalah. Adapun hasil penelitian dari Kavrayici (2020) diketahui hubungan antara keterampilan komunikasi dan kompetensi manajemen kelas berada dalam kategori sedang dari keterampilan pemecahan masalah mahasiswa calon guru di Turki. Penelitian lainnya yang dilakukan oleh Putri (2019) diketahui bahwa keterampilan pemecahan masalah mengalami peningkatan yang sangat efektif melalui pembelajaran yang melatihkan keterampilan komunikasi mahasiswa. Ini sejalan dengan hasil penelitian dari Hartati (2017) yang menyatakan bahwa keterampilan komunikasi memiliki hubungan yang cukup kuat dan signifikan dengan keterampilan pemecahan masalah dengan kategori sedang.

Berdasarkan pemaparan di atas, maka akan dilakukan penelitian yang berjudul "Hubungan Keterampilan Komunikasi Abad 21 dan Keterampilan Pemecahan Masalah Mahasiswa Pendidikan Fisika" yang bertujuan untuk menganalisis hubungan antara keterampilan komunikasi dengan keterampilan pemecahan masalah mahasiswa pendidikan fisika.

\section{METODE PENELITIAN}

Penelitian ini merupakan penelitian kuantitatif non eksperimental berupa penelitian korelasional yang bertujuan untuk mengetahui hubungan antara keterampilan berkomunikasi (communication skill) abad 21 terhadap keterampilan pemecahan masalah (problem solving skill) dan untuk mengetahui kontribusi keterampilan berkomunikasi abad 21 terhadap keterampilan pemecahan masalah mahasiswa Pendidikan Fisika (Fraenkel, 2008).

Subjek penelitian yaitu mahasiswa Pendidikan Fisika Universitas Siliwangi yang mengambil mata kuliah mekanika semester ganjil tahun akademik 2019/2020 sebanyak 65 mahasiswa yang terdiri dari dua kelas. Kelas A terdiri dari 32 mahasiswa dan kelas B terdiri dari 33 mahasiswa. Data diperoleh melalui lembar observasi keterampilan komunikasi abad 21, tes uraian berkasus pada materi gerak harmonik teredam sebanyak 5 soal dan wawancara.

Pada lembar observasi keterampilan komunikasi abad 21 mahasiswa pendidikan fisika terdapat tiga aspek yang dinilai yaitu sistematika atau format, penggunaan bahasa, kelengkapan isi dan urutan isi. Untuk lebih jelasnya dapat dilihat pada Tabel 1. 
JoTaLP: Journal of Teaching and Learning Physics 6, 1 (2021): 1-10

Website: http://journal.uinsgd.ac.id/index.php/jtlp/index ISSN 2580-3107 (online) ISSN 2528-5505 (print)

Tabel 1. Indikator Keterampilan Komunikasi Abad 21

\begin{tabular}{|c|c|c|}
\hline & ek & Skor \\
\hline \multirow{3}{*}{$\begin{array}{l}\text { Sistematika/ } \\
\text { format }\end{array}$} & $\begin{array}{l}\text { Mampu menyampaikan } \\
\text { gagasan/hasil diskusi ke } \\
\text { dalam kerangka tapi belum } \\
\text { lengkap. }\end{array}$ & 1 \\
\hline & $\begin{array}{l}\text { Mampu menyampaikan } \\
\text { gagasan/hasil diskusi ke } \\
\text { dalam kerangka secara } \\
\text { lengkap dan sistematis. }\end{array}$ & 2 \\
\hline & $\begin{array}{l}\text { Mampu menyampaikan } \\
\text { gagasan/hasil diskusi ke } \\
\text { dalam kerangka secara } \\
\text { lengkap/utuh, sistematis } \\
\text { dan padu serta lancar. }\end{array}$ & 3 \\
\hline \multirow{3}{*}{$\begin{array}{c}\text { Penggunaan } \\
\text { bahasa }\end{array}$} & \begin{tabular}{lr} 
Mampu & \multicolumn{2}{r}{ menanggapi } \\
ungkapan gagasan teman \\
dengan cara & bertanya, \\
berpendapat & dan \\
memberikan & masukan \\
dengan bahasa yang singkat.
\end{tabular} & 1 \\
\hline & \begin{tabular}{lr} 
Mampu & \multicolumn{2}{r}{ menanggapi } \\
ungkapan gagasan teman \\
dengan cara bertanya, \\
berpendapat ran \\
memberikan masukan \\
dengan bahasa yang singkat \\
\multicolumn{2}{l}{ santun dan jelas. } \\
\end{tabular} & 2 \\
\hline & $\begin{array}{lr}\text { Mampu menanggapi } \\
\text { ungkapan gagasan teman } \\
\text { dengan cara bertanya, } \\
\text { berpendapat dan } \\
\text { memberikan masukan } \\
\text { dengan bahasa yang singkat, } \\
\text { jelas dan santun serta } \\
\text { komunikatif. }\end{array}$ & 3 \\
\hline \multirow{3}{*}{$\begin{array}{l}\text { Kelengkapan } \\
\text { isi dan } \\
\text { urutan isi }\end{array}$} & $\begin{array}{l}\text { Mampu menceritakan } \\
\text { kembali pokok-pokok teks } \\
\text { secara lengkap meskipun } \\
\text { belum berurutan. }\end{array}$ & 1 \\
\hline & $\begin{array}{l}\text { Mampu menceritakan } \\
\text { kembali pokok-pokok teks } \\
\text { secara lengkap dan } \\
\text { berurutan namun masih ada } \\
\text { pokok-pokok yang tidak } \\
\text { sesuai dengan tema. }\end{array}$ & 2 \\
\hline & $\begin{array}{lrr}\text { Mampu } & \text { menceritakan } \\
\text { kembali } & \text { pokok-pokok } & \text { teks } \\
\text { secara } & \text { lengkap } & \text { dan }\end{array}$ & 3 \\
\hline
\end{tabular}

\begin{tabular}{ccc}
\hline Penilaian Aspek & Skor \\
\hline $\begin{array}{l}\text { berurutan sesuai } \\
\text { tema laporan. }\end{array}$ & dengan & \\
\hline
\end{tabular}

Hasil penilaian lembar observasi kemudian dikategorikan berdasarkan kriteria seperti tabel berikut.

Tabel 2. Kriteria Penilaian Observasi Keterampilan Komunikasi Abad 21

\begin{tabular}{cc}
\hline Kategori & Skor \\
\hline Baik & $7-9$ \\
\hline Cukup & $4-6$ \\
\hline Kurang & $1-3$ \\
\hline
\end{tabular}

Lembar observasi keterampilan komunikasi digunakan untuk menilai penampilan presentasi mahasiswa ketika menyampaikan permasalahan, solusi dan rencana yang akan dilakukan terkait materi gerak harmonik teredam.

Adapun Aspek Penilaian (AP) keterampilan pemecahan masalah yang dinilai yaitu mendefinisikan masalah (AP1), memeriksa masalah (AP2), merencanakan solusi (AP3), melaksanakan rencana yang telah dibuat (AP4) dan mengevaluasi (AP5) dengan rubrik penilaian tes keterampilan pemecahan masalah sebagai berikut.

Tabel 3. Rubrik Penskoran Keterampilan Pemecahan Masalah

\begin{tabular}{lc}
\hline \multicolumn{1}{c}{ Kategori } & Skor \\
\hline $\begin{array}{l}\text { Mahasiswa tidak menuliskan atau tidak } \\
\text { menjawab apapun. }\end{array}$ & 0 \\
\hline $\begin{array}{l}\text { Mahasiswa menjawab dengan jawaban } \\
\text { yang salah. }\end{array}$ & 1 \\
\hline $\begin{array}{l}\text { Mahasiswa menjawab hampir benar tanpa } \\
\text { disertai penjelasan/alasan. }\end{array}$ & 2 \\
\hline $\begin{array}{l}\text { Mahasiswa menjawab benar disertai } \\
\text { penjelasan/alasan yang kurang tepat. }\end{array}$ & 3 \\
\hline $\begin{array}{l}\text { Mahasiswa menjawab dengan benar } \\
\text { disertai penjelasan/alasan yang tepat. }\end{array}$ & 4 \\
\hline
\end{tabular}

Hasil penilaian keterampilan pemecahan masalah kemudian dikategorikan berdasarkan kriteria pada Tabel 4. 
Tabel 4. Kriteria Penilaian Observasi Keterampilan Pemecahan Masalah

\begin{tabular}{cc}
\hline Kategori & Skor \\
\hline Baik & $14-20$ \\
\hline Cukup & $8-13$ \\
\hline Kurang & $1-7$
\end{tabular}

Rubrik penskoran keterampilan pemecahan masalah digunakan dalam menilai jawaban yang diberikan mahasiswa pada tes uraian berkasus pada materi gerak harmonik teredam sebanyak 5 soal.

Persentase kontribusi keterampilan komunikasi terhadap keterampilan pemecahan masalah didapatkan dengan menghitung Koefisien Determinasi (KD) menggunakan persamaan berikut:

$$
K D=r^{2} \times 100 \%
$$

dengan $r$ merupakan nilai koefisien korelasi.

\section{HASIL DAN PEMBAHASAN}

Berdasarkan hasil pengamatan, peneliti menyajikan data kedua kelas dikarenakan terdapat perbedaan karakteristik dan kecepatan mahasiswa dalam memahami materi perkuliahan. Karakteristik kelas A lebih serius ketika pembelajaran dan lebih cepat memahami materi ketika perkuliahan sedangkan kelas B karakteristiknya lebih santai tetapi aktif dan suasana pembelajarannya lebih riang dan menyenangkan ketika memahami materi perkuliahan. Hasil data yang diperoleh dari dua kelas A dan B yang berjumlah 65 mahasiswa Pendidikan Fisika Universitas Siliwangi diketahui bahwa keterampilan komunikasi (Communication Skills) abad 21 dan keterampilan pemecahan masalah (Problem Solving Skills) keduanya berada dalam kategori baik seperti yang dapat dilihat pada Gambar 1 .

Observer mengamati bahwa mahasiswa dapat menyampaikan ide atau gagasan dengan percaya diri sehingga lancar ketika berkomunikasi dan menyampaikan solusi permasalahan dengan menyenangkan sehingga menarik minat pendengar. Ini sesuai dengan penelitian yang dilakukan oleh Pribadi (2019) bahwa kepercayaan dan harga diri berpengaruh secara signifikan dalam kategori tinggi yaitu 0,71 . Selain itu, observer juga menilai mahasiswa sudah terampil mengatasi situasi yang tidak sesuai perkiraan sehingga tetap tercipta suasana yang efektif dan menyenangkan ketika berkomunikasi seperti mencairkan suasana yang kaku menjadi lebih menyenangkan dan interaktif. Observer juga menilai kompetensi digital mahasiswa pendidikan fisika juga baik terlihat dari penyampaian materi dengan menggunakan teknologi yang mendukung penyampaian materi lebih maksimal, menyenangkan dan interaktif. Hal ini sejalan dengan yang dikemukan oleh Muste (2016) selain keterampilan berbahasa, mahasiswa juga harus dapat menggunakan teknologi untuk menunjang keterampilan komunikasinya.

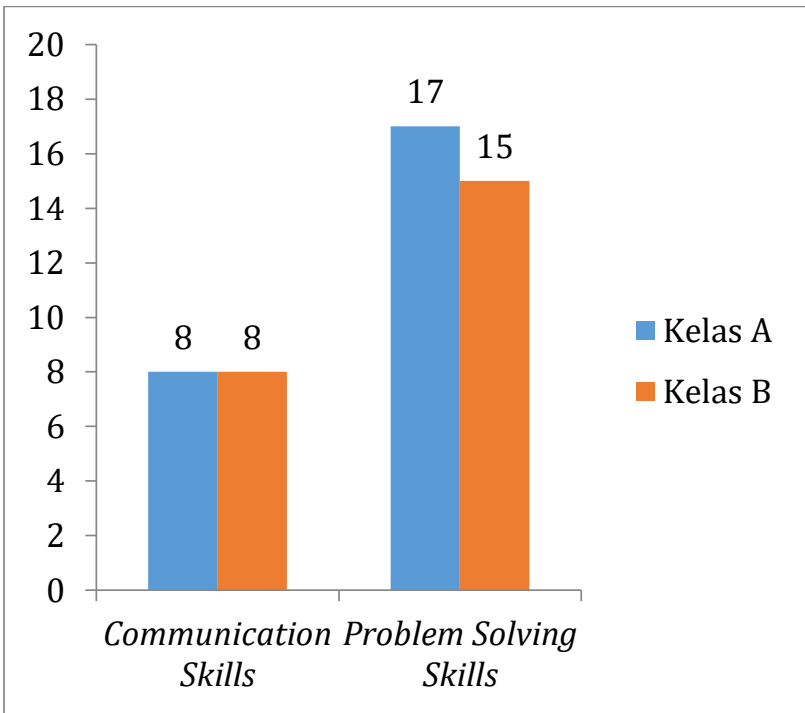

Gambar 1. Hasil observasi keterampilan komunikasi dan keterampilan pemecahan masalah mahasiswa Pendidikan Fisika

Teknologi dijadikan media dalam menyalurkan kreativitas dan mengkomunikasikan pesan positif yang ingin disampaikan kepada pendengar. Ini 
sejalan dengan penelitian yang telah dilakukan oleh oleh Asrar (2018), Khan (2017) dan Marzuki (2015) menyatakan hal yang sama bahwa keterampilan komunikasi sangat didukung oleh keterampilan berbahasa dan keterampilan teknologi. Adapun hasil pengamatan dari ketiga aspek keterampilan komunikasi mahasiswa pendidikan fisika kelas A dan B dapat dilihat pada Gambar 2.

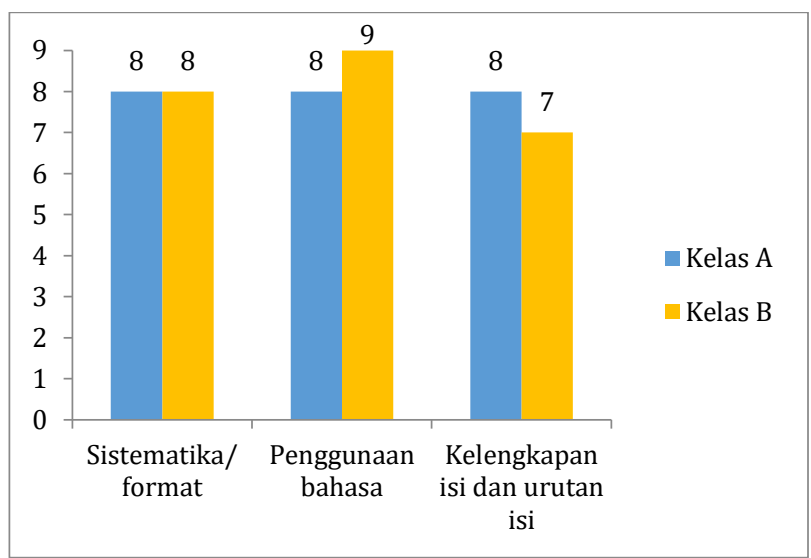

Gambar 2. Hasil observasi setiap aspek keterampilan komunikasi mahasiswa Pendidikan Fisika

Berdasarkan data di atas, meskipun rata-rata keterampilan komunikasi antara kedua kelas sama tetapi skor untuk penggunaan bahasa dan kelengkapan serta urutan isi berbeda. Mahasiswa kelas B lebih baik dalam penggunaan bahasa dibandingkan kelas A. Mahasiswa kelas B lebih terampil menggunakan bahasa yang komunikatif, menyenangkan dan tidak terlalu kaku ketika berkomunikasi sehingga suasana lebih menarik. Namun untuk aspek kelengkapan dan urutan isi, mahasiswa kelas A lebih baik dibandingkan kelas B. Mahasiswa kelas A lebih lengkap dan berurutan ketika berkomunikasi dengan menyampaikan solusi permasalahan dengan lebih mendalam. Adapun kategori persentase setiap indikator dari keterampilan komunikasi abad 21 dapat dilihat pada tabel berikut 5 . Adapun hasil penilaian soal uraian berkasus sebanyak 5 soal diketahui kelima aspek keterampilan pemecahan masalah mahasiswa pendidikan fisika kelas A dan B yang dapat dilihat pada Gambar 3.

Tabel 5. Persentase Kategori Keterampilan Komunikasi Abad 21 Mahasiswa Pendidikan Fisika

\begin{tabular}{ccc}
\hline \multicolumn{2}{c}{ Penilaian Aspek } & Persentase \\
\hline Sistematika/ & Baik & $75 \%$ \\
\cline { 2 - 3 } format & Cukup & $25 \%$ \\
\hline Penggunaan & Baik & $85 \%$ \\
\cline { 2 - 3 } bahasa & Cukup & $15 \%$ \\
\hline $\begin{array}{c}\text { Kelengkapan } \\
\text { isi dan }\end{array}$ & Baik & $70 \%$ \\
\cline { 2 - 3 } urutan isi & Cukup & $30 \%$ \\
\hline
\end{tabular}

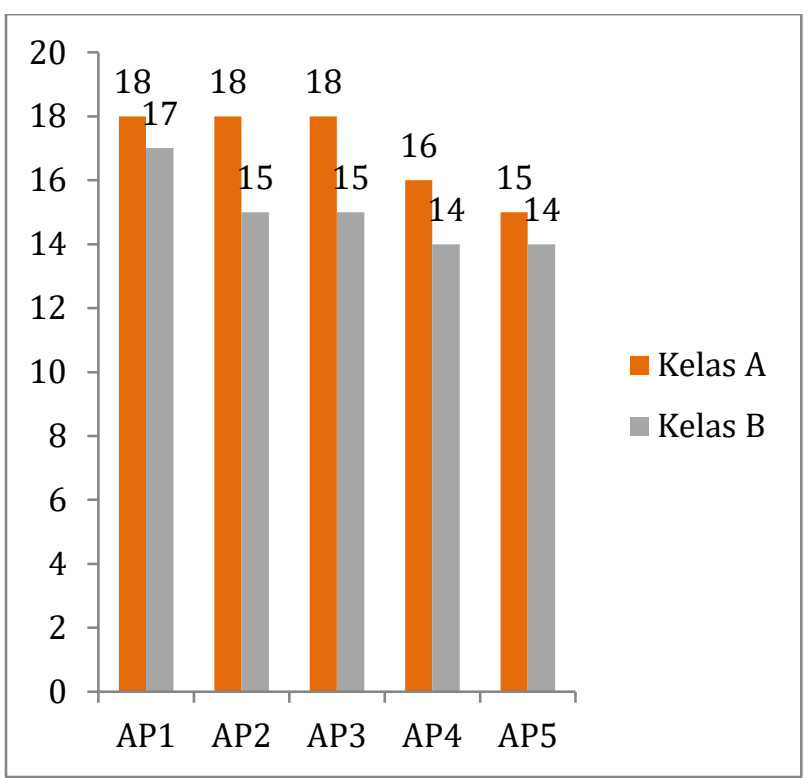

Gambar 3. Hasil observasi setiap aspek keterampilan pemecahan masalah mahasiswa Pendidikan Fisika

Hasil pengamatan di atas menunjukkan bahwa kelas A memiliki keterampilan pemecahan masalah yang lebih baik dari kelas B. Hal tersebut ditunjukkan dengan rata-rata skor keterampilan pemecahan masalah kelas A lebih besar daripada kelas B. Observer mengamati pada AP1, mahasiswa kelas A lebih terampil dalam dapat menyebutkan fakta permasalahan, menentukan konsep, informasi dan data yang terkait masalah yang diberikan serta dapat menentukan detail masalah. Untuk AP2 mahasiswa kelas A juga lebih 
baik dalam mengidentifikasi akar masalah, menentukan hubungan sebab-akibat dari permasalahan yang diberikan dan menentukan solusi yang akan dilakukan untuk menyelesaikan masalah yang diberikan. Pada AP3, mahasiswa kelas B tidak sebaik kelas A dalam mengembangkan rencana pemecahan masalah berdasarkan akar masalah dan memilih teori, prinsip dan pendekatan untuk memecahkan masalah yang diberikan. Pada AP4, mahasiswa kelas A juga lebih baik dalam mengurutkan langkah kerja dari solusi yang akan dilakukan dan menentukan pihak yang dapat bekerja sama dalam pelaksanaan solusi. Untuk AP5, mahasiswa kelas A lebih baik dalam menilai hasil yang akan diperoleh melalui solusi yang telah dilakukan dengan mempertimbangkan beberapa aspek penilaian mulai dari aspek ilmu pengetahuan, teknologi, ekonomi dan sosial. Untuk lebih jelasnya dapat dilihat kategori persentase mahasiswa seperti pada Tabel 6.

Tabel 6. Persentase Kategori Keterampila Pemecahan Masalah Mahasiswa Pendidikan Fisika

\begin{tabular}{lcc}
\hline \multicolumn{1}{c}{ Penilaian Aspek } & Kategori & Persentase \\
\hline \multirow{2}{*}{ Mendefinisikan masalah } & Baik & $75 \%$ \\
\cline { 2 - 3 } & Cukup & $25 \%$ \\
\hline \multirow{2}{*}{ Memeriksa masalah } & Baik & $65 \%$ \\
\cline { 2 - 3 } & Cukup & $35 \%$ \\
\hline \multirow{3}{*}{ Merencanakan solusi } & Baik & $70 \%$ \\
\cline { 2 - 3 } & Cukup & $25 \%$ \\
\cline { 2 - 3 } & Kurang & $5 \%$ \\
\hline \multirow{2}{*}{ Melaksanakan rencana } & Baik & $65 \%$ \\
\cline { 2 - 3 } yang telah dibuat & Cukup & $30 \%$ \\
\cline { 2 - 3 } & Kurang & $5 \%$ \\
\hline \multirow{3}{*}{ Mengevaluasi } & Baik & $60 \%$ \\
\cline { 2 - 3 } & Cukup & $35 \%$ \\
\cline { 2 - 3 } & Kurang & $5 \%$ \\
\hline
\end{tabular}

Hasil penelitian di atas sejalan dengan penelitian yang dilakukan sebelumnya oleh Wardani (2015), Kuntadi (2016), Karmana (2019) dan Wakit (2020) bahwa keterampilan pemecahan masalah yang dilatihkan melalui pembelajaran dipengaruhi oleh potensi akademik dan gaya kognitif sehingga meskipun kedua kelas penelitian memiliki kategori keterampilan pemecahan masalah yang sama akan tetapi kedua faktor tersebut membedakan kualitasnya.

Selanjutnya hasil uji korelasional diperoleh koefisien korelasi antara keterampilan komunikasi dan keterampilan pemecahan masalah kedua kelas berada dalam kategori sedang dengan nilai $r$ yaitu 0,50 . Untuk lebih jelasnya ditunjukkan pada Gambar 4.

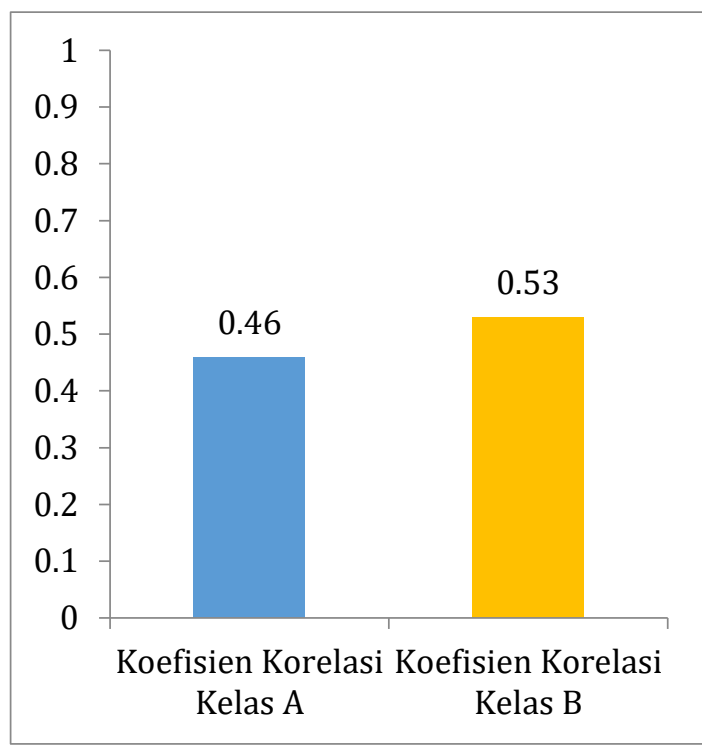

Gambar 4. Hasil uji korelasional keterampilan komunikasi terhadap keterampilan pemecahan masalah kelas A dan B

Berdasarkan hasil uji korelasional maka diketahui terdapat korelasi yang positif antara keterampilan komunikasi abad 21 dengan keterampilan pemecahan masalah. Artinya, semakin terampil mahasiswa berkomunikasi maka semakin terampil juga mahasiswa memecahkan permasalahan yang diberikan. Hal ini sesuai dengan penelitian yang telah dilakukan sebelumnya oleh Kvrayici (2020) dan Aküzüm (2017) yang menyatakan bahwa terdapat hubungan yang positif antara keterampilan pemecahan masalah, keterampilan komunikasi dan kompetensi manajemen kelas. Keterampilan pemecahan masalah dari mahasiswa merupakan mediator yang sempurna dalam hubungan antara 
keterampilan komunikasi dan kompetensi manajemen kelas. Penelitian lain yang dilakukan oleh Putri (2019) juga menyatakan bahwa melatihkan keterampilan komunikasi kepada mahasiswa sangat efektif dalam meningkatkan keterampilan pemecahan masalah karena mahasiswa belajar lebih aktif dengan berkelompok dengan mengemukakan ide dan pendapat serta menanggapi solusi yang diajukan untuk memecahkan masalah yang diberikan.

Peneliti juga memperoleh hasil persentase kontribusi keterampilan komunikasi terhadap keterampilan pemecahan masalah sebesar $25 \%$. Hasil ini sesuai dengan penelitian sebelumnya yang dilakukan oleh Koc (2015), Hartati (2017) dan Gülbahar (2018) yang menyatakan bahwa hubungan antara keterampilan komunikasi dengan keterampilan pemecahan masalah cukup kuat dan signifikan dengan kontribusinya sebesar $30 \%$. Penelitian lain yang dilakukan oleh Hidayati (2020) menunjukkan bahwa keterampilan komunikasi dan kolaborasi memberikan kontribusi yang efektif sebesar $44,61 \%$ terhadap keterampilan pemecahan masalah.

\section{KESIMPULAN}

Berdasarkan hasil analisis data dan hasil pengamatan yang dilakukan oleh observer maka dapat disimpulkan bahwa terdapat korelasi positif dengan kategori sedang antara keterampilan komunikasi abad 21 terhadap keterampilan pemecahan masalah. Keterampilan komunikasi ini memberikan kontribusi sebesar $25 \%$ terhadap keterampilan pemecahan masalah.

Adapun rekomendasi untuk penelitian selanjutnya yaitu: (1) Menggali lebih dalam lagi variabel-variabel lain yang memiliki hubungan yang kuat dengan keterampilan pemecahan masalah. (2) Menambahkan variabel lain yang dianalisis selain keterampilan komunikasi yang diprediksikan memiliki hubungan dengan keterampilan pemecahan masalah seperti pemahaman konsep atau keterampilan berpikir kreatif. (3) Mencoba menerapkan model lain sebagai perbandingan untuk menentukan efektivitas penerapan model dalam meningkatkan keterampilan komunikasi dan keterampilan pemecahan masalah.

Saran yang dapat dilakukan untuk penelitian selanjutnya yaitu: (1) Merumuskan waktu presentasi mahasiswa yang disepakati bersama agar lebih teratur. (2) Kegiatan observasi dilakukan minimal setelah 3 kali pertemuan supaya mendapatkan gambaran peningkatan keterampilan-keterampilan yang diamati.

\section{UCAPAN TERIMA KASIH}

Ucapan terima kasih kepada semua pihak yang telah membantu peneliti selama proses penelitian terutama kepada ketua jurusan Pendidikan Fisika Universitas Siliwangi, observer dan mahasiswa Pendidikan Fisika angakatan 2018 yang telah bekerja sama dengan baik sehingga penelitian berjalan dengan lancar dan menyenangkan. Peneliti berharap semoga penelitian ini bermanfaat dan dapat menjadi motivasi untuk lebih baik lagi.

\section{DAFTAR PUSTAKA}

Malik, A., Dirgantara, Y., Mulhayatiah, D., \& Agustina, R.D. (2020). Analisis hakikat, peran dan implikasi kegiatan laboratorium terhadap keterampilan abad 21. Conference of Workshop UIN Sunan Gunung Djati Bandung, 1-12, Bandung: LP2M UIN Sunan Gunung Djati Bandung.

Duta, N. (2015). From theory to practice: the barriers to communication in teacherstudent relationship. Procedia-Social and Behavioral Sciences, 625-630, Ankara: Pegem Yayıncilı.

Argaw, A.S, Haile, B.B., Ayalew, B.T., \& Kuma, S.G. (2016). The effect of problem-based learning (PBL) instruction on students' motivation and problem-solving skills of physics. Eurasia Journal of Mathematics Science and Technology Education, 13(3), 857-871. 
Rahman, dkk. (2020). Literasi dalam konteks keterampilan komunikasi abad 21 pada mahasiswa pendidikan guru sekolah dasar. Makalah disajikan dalam Lokakarya Pengelolaan dan Penyuntingan Jurnal Ilmiah, Bandung: Universitas Pendidikan Indonesia.

Saputro, B. (2020). Pengembangan model problem based learning dalam meningkatkan keterampilan komunikasi ilmiah calon guru IPA era revolusi industri 4.0. Salatiga: Aswaja Pressindo.

Makiyah, Y.S., Malik, A., Susanti, E., \& Mahmudah, I.R. (2019). Higher order thinking real and virtual laboratory (HOTRVL) untuk meningkatkan keterampilan abad ke-21 mahasiswa pendidikan fisika. Jurnal Diffraction, 1(1), 1-5.

Pahlevi, I., Rudibyani, R. B., \& Sofya, E. (2020). Penerapan model problem solving untuk meningkatkan keterampilan komunikasi dan penguasaan konsep asam basa siswa. Jurnal Pendidikan dan Pembelajaran Kimia, 9(1), 1-9.

Safitri, M. (2019). Pengaruh LKS berbasis problem solving untuk meningkatkan keterampilan komunikasi dan kolaborasi siswa. Skripsi, Fakultas Keguruan dan Ilmu Pendidikan: Universitas Lampung.

Muhajir, S.N., Mahen, E.C.S., Yuningsih, E.K., \& Rochman, C. (2015). Implementasi model problem solving laboratory untuk meningkatkan kemampuan literasi mahasiswa pada mata kuliah fisika dasar II. Prosiding Simposium Nasional dan Pembelajaran Sains 2015, 1-12, Bandung: Institut Teknologi Bandung.

Zulianti, Y. (2017). Efektivitas pembelajaran menggunakan LKS berbasis problem solving dalam meningkatkan keterampilan mengkomunikasikan pada materi asam basa. Skripsi, Fakultas Keguruan dan Ilmu Pendidikan: Universitas Lampung.

Medriati, R., \& Risdianto, E. (2020). Penerapan pendekatan student centered learning (SCL) untuk meningkatkan keterampilan berpikir kreatif dan komunikatif mahasiswa pendidikan fisika semester III universitas Bengkulu. Journal Kumparan Fisika, 3(1), 67-74.

Novitasari, N., Ramli, M., \& Maridi. (2015). Mengukur problem skilla siswa pada mata pelajaran biologi. Jurnal Biologi Edukasi, 7(1), 1-6.

Häkkinen, P., Järvelä, S., Siegl, K., Ahonen, A., Näykki, P., \& Valtonen, T. (2017). Preparing teacher-students for twenty-first-century learning practices (PREP 21): a framework for enhancing collaborative problemsolving and strategic learning skills. Teachers and Teaching, 23(1), 25- 41.

Kvrayici, C. (2020). Communication skills and classroom management competency: the mediating role of problem solving skills, Journal of Teacher Education and Educators, 9(1), 125-137.

Putri, R., Jumadi, Ariswan, \& Oktasari, D. (2019). The effectiveness of teachers' use of lecture model combined with cooperative learning method for enhancing students' problemsolving skills in physics. Jurnal Penelitian dan Pengembangan Pendidikan Fisika, 5(2), 83-90.

Hartati, S., Abdulloh I., \& Haji, S. (2017). Pengaruh kemampuan pemahaman konsep, kemampuan komunikasi dan koneksi terhadap kemampuan pemecahan masalah. Journal of Mathematics Education, Science and Technology, 2(1), 43-72.

Fraenkel, dkk. (2008). How to Design and Evaluate Research in Education (4th Ed.). US: McGraw-Hill Comp.

Pribadi, E.A., \& Erdiansyah, R. (2019). Pengaruh kepercayaan diri dan harga diri terhadap keterampilan komunikasi interpersonal remaja di Jakarta. Jurnal Koneksi, 3(2), 453462.

Muste, D. (2016). The role of communication skills in teaching process, The European Proceeding of Social and Behavioural Science, 429-434, UK: Education, Reflection, Development, Fourth Edition.

Asrar, Z. (2018). The impact of communication between teachers and students: A case 
study of the Faculty of Management Sciences University of Karachi, Pakistan. European Scientific Journal, 14(16), 32-39.

Khan, A. (2017). Communication skills of a teacher and its role in the development of the students' academic success. Journal of Education and Practice, 8(1), 18-21.

Marzuki, N.A, Mustaffa, C.S., \& Saad, Z.M. (2015). Communication and information technology skills. Asian Social Science, 11(15), 267-274.

Wardani, E.D. (2015). Peningkatan keterampilan pemecahan masalah matematika SMP melalui strategi discovery learning. Skripsi, Fakultas Keguruan dan Ilmu Pendidikan: Universitas Muhammadiyah Surakarta.

Kuntadi, D., \& Grace, H.L. (2016). Penerapan model pembelejaran anchored instruction untuk meningkatkan kemampuan pemecahan masalah peserta didik pada materi kalor. Journal of Teaching and Learning Physics, 1(1), 13-18.

Karmana, I.W, Dharmawibawa, I.D, \& Hajiriah, T.L. (2019). Efektivitas strategi PBL berbasis potensi akademik terhadap keterampilan pemecahan masalah dan berpikir kritis siswa SMA pada topik lingkungan. Jurnal Ilmiah Mandala Education, 6(1), 20-26.

Wakit, A., \& Hidayati, N. (2020). Kemampuan pemecahan masalah matematika mahasiswa teknik sipil ditinjau dari gaya kognitif. Jurnal Matematika Kreatif-Inovatif, 11(1), 101-109.

Aküzüm, C, Özdemir Gültekin, S . (2017). Sınıf öğretmenlerinin iletişim becerileri ile sınıf yönetimi becerileri arasındaki ilişkinin incelenmesi [Examining the relationship between primary school teachers' communication skills and classroom management skills]. Electronic Journal of Education Sciences, 6 (12), 88-107.

Koç, B., Terzi, Y., \& Gül, A. (2015). Üniversite öğrencilerinin iletişim becerileri ile kişilerarası problem çözme becerileri arasındaki ilişki [The relationship between university students' interpersonal problem-solving skills and teachers' communication skills]. Uluslararası Türkçe Edebiyat Kültür Eğitim Dergisi, 4(1), 369390.

Gülbahar, B., \& Sıvacı, S. Y. (2018). Öğretmen adaylarının iletişim becerileri ile sınıf yönetimi yeterlik algıları arasındaki ilişkinin incelenmesi [Examining the relationship between preservice teachers' communication skills and classroom management competency perceptions] Yüzüncü Yll Üniversitesi Eğitim Fakültesi Dergisi, 15(1), 268-301.

Hidayati, N., Zubaidah, S., Suarsini, E., \& Praherdhiono, H. (2020). Cognitive learning outcomes: its relationship with communication skills and collaboration skills through digital mind maps-integrated PBL. International Journal of Information and Education Technology, 10(6), 443-448. 